\title{
THE ROLE OF THE JUDICIARY WITHIN THE CONSTRuCtion OF COLLECTIVE MEMORY. THE ITALIAN TRANSITION
}

\author{
Paolo Caroli*
}

\section{INTRODUCTION}

This article will focus on the Italian transition from the Fascist regime, which lasted from 1922 (although officially evolving into a dictatorship in 1925) to 1943, to the democratic Republic, which was proclaimed in 1946 and established in 1948. It will analyse how Italy has been dealing with Fascist and Nazi crimes, and in particular with its own national responsibilities related to those crimes.

The criminal prosecution of Fascist crimes is especially interesting for criminal lawyers due to the many relevant issues involved, such as the legal qualification of the crimes, the manner in which the legislator and the judiciary have dealt with the basic principle of criminal law, for example the principle of non-retroactivity or the definition of the concept of political crime. For transitional justice scholars, this area is even more interesting, because the transition began almost two years before the end of the conflict, while half of the country was still under Nazi and Fascist occupation. Furthermore, it is intriguing due to the decisive role of the amnesty law, which was implemented a very short time after the end of the war, much earlier than in other European countries.

In the vast, heterogeneous and controversial spectrum of the Italian transition, ${ }^{1}$ this article will highlight the role of the Italian judiciary in the

DOI: $10.1515 /$ wrlae-2015-0030

* Phd Candidate in the Doctoral Programme of Comparative and European Legal Studies, University of Trento, Italy.

${ }^{1}$ On the Italian transition, from a juridical point of view, see Giuliano Vassalli and Giuseppe Sabatini, Il collaborazionismo e l'amnistia politica nella giurisprudenza della Corte di Cassazione (La Giustizia penale 1947), Emanuela Fronza, 'La persecución de los crímenes nazi-fascistas en Italia' (2011) 93 Revista Brasilieira de Ciencias Criminais 225; Massimo Donini, 'La gestione penale del passaggio dal fascismo alla Repubblica in Italia' (2009) XXXIX 1 Materiali per una storia della cultura giuridica 183; Guido Neppi Modona (ed), Giustizia penale e guerra di liberazione (Franco Angeli 1984); Paolo Barile and Ugo De Siervo, 'Le sanzioni contro il fascismo e il neofascismo' (1969) XVI NSSDI 541; Achille Battaglia, I giudici e la politica (Laterza 1962); Carlo Galante Garrone, 'Guerra di liberazione (dalle galere)' (1947) 3 Il Ponte 292; Sergio Seminara, 'Die Aufarbeitung der faschistischen Vergangenheit in Italien. Strafrechtliche Probleme' (2014) 15 Jahrbuch der Juristischen Zeitgeschichte 3; Gabriele Fornasari, Giustizia di transizione e diritto penale (Giappichelli 2013). From an historical point of view, see Hans Woller, Die Abrechnung mit dem 
trials against the Fascist criminals. This role cannot be considered as a mere application of the law, in fact on many occasions it resulted in an obvious attempt to grant impunity for the highest hierarchs of the former regime.

As will be described in the second part of the article, the (certainly not positive) outcomes of the criminal prosecution of Fascist crimes, combined with other political and social factors, had a very important effect on the creation of a collective memory of those events. In this collective memory, the Italian responsibilities before and during the war (crimes against political opponents, colonialists and racial crimes, the role of Italian citizens in the anti-Semitic propaganda, ${ }^{2}$ in the deportation of Jews, their contribution to the crimes committed by the Nazis against the Italian civil population) were quickly forgotten and hidden behind those committed by the Nazis.

\section{The Double Path in the Prosecution of Fascist and Nazi CRIMES}

Germany, Italy and Japan formed the Berlin-Rome-Tokyo Axis in the 1930s, establishing an alliance, which started as political, with the creation of the Berlin-Rome Axis and the Anti-Comintern Pact in 1936. The alliance officially became a military one with the so called Pact of Steel between Italy and Germany in 1939 and the Tripartite Pact in 1940. The latter consisted of a division of the world into spheres of interest. ${ }^{3}$ At the end of the war, Germany and Japan were undoubtedly the defeated powers of the Axis and they were put on trial in Nuremberg and Tokyo respectively. Italy, by contrast, had vague and multiple identities.

On the one hand, members of the Fascist regime committed crimes in Italy and abroad starting from the coup of 1922. On the other hand, the distinctive and crucial trait of Italy is the so-called Badoglio Armistice between the Kingdom of Italy and the Allies, proclaimed on the $8^{\text {th }}$ of September, 1943. With this armistice, Italy turned from being an ally of Germany into a traitor. More precisely, a second armistice was signed in Malta on the $29^{\text {th }}$ of September, 1943 and the declaration of war against Germany followed on the $13^{\text {th }}$ October, 1943. After that, as a result of the mediation by General Eisenhower between the U.S. President Roosevelt and the Italian King Victor Emmanuel III, Italy gained the status of cobelligerent with the Allies. In the South, a government led by Lieutenant Badoglio was formed which preserved the constitutional structure of the Kingdom, although originally its sovereignty was limited to a part of the region of Apulia (the provinces of Lecce, Taranto, Bari and Brindisi), as the rest of the South was

\footnotetext{
Faschismus in Italien, 1943-1948 (Oldenbourg 1996); Mimmo Franzinelli, L'amnistia Togliatti. 22 giugno 1946. Colpo di spugna sui crimini fascisti (Mondadori 2006); Toni Rovatti, Leoni vegetariani. La violenza fascista durante la RSI (Clueb 2011); Michele Battini, La mancata Norimberga italiana (Laterza 2003); Romano Canosa, La storia dell'epurazione in Italia: le sanzioni contro il fascismo 1943-1948 (Baldini \& Castoldi 1999). 2 The so called Italian Racial Laws started to be introduced in 1938 and Italian Jewish students were removed from public schools already in 1938, even before a similar law was issued in Germany. In this regard, Filipppo Focardi, Il cattivo Tedesco e il bravo italiano (Laterza 2014).

${ }^{3}$ See Frederick William Deakin, The Brutal Friendship. Mussolini, Hitler and the fall of Italian Fascism (Harper and Row 1962).
} 
controlled by the Allied Military Government for Occupied Italy. The North and Centre, which were under the control of German troops, became de facto occupied lands. Although, a puppet state of Germany - the Italian Social Republic (informally known as the Republic of Salò) - was established in the occupied North.

The Italians as a people, since the 8th of September, 1943, had a dual nature of both aggressors and victims. Some Italians collaborated with the German enemy, others fought against it, while many Italians were victims of Nazi crimes. In the field of transitional justice, the main consequence of this dual nature was the creation of a double path ${ }^{4}$ in the criminal prosecution of war crimes, which varied depending on the nationality of the perpetrators: Italian or German. The effects of this division went beyond the criminal prosecution and, as we will see, nationality was the catalyst for the divergence of the memory paths, eventually resulting in a process which results in both memory paths and oblivion paths.

As for criminal prosecution, this double path was characterized by different jurisdictions and applicable laws. German citizens, as members of an occupying power, were tried for war crimes by military courts under the Military Penal Code of War of 1941.

The war crimes committed by Italians were judged first by special courts ${ }^{5}$ and later by ordinary courts. The legal basis was new norms specifically introduced in order to punish Fascist crimes. In fact a process of "defascistization" was required by the second Armistice with the Allies. The Allied Military Government itself was the first to begin the lustration of former Fascists from the public administration, this should then have been continued by the Italian government as the territories came under its control ${ }^{6}$.

The whole complex history of lustration and punishment of Fascists in Italy demonstrates another unique aspect of the Italian transition. Differently from Germany and Japan, the showdown with the past regime within Italian society did not begin as it had already been defeated. As a matter of fact, it took place while the Fascist regime was still alive and fighting in a significant part of the country (in the form of the Italian Social Republic), and while it would take almost two years of war to defeat it, a war that soon became civil and eventually even threatened to turn into a class war. ${ }^{7}$ New provisions were introduced in order to punish Fascist crimes (Royal Decree-Law of the $26^{\text {th }}$ of May, 1944, $\mathrm{n}^{\circ} 134$ and Legislative Decree of the Lieutenant of the Realm of the $27^{\text {th }}$ of July, $1944 \mathrm{n}^{\circ} 159$ ), but they aimed at coordinating and enabling implementation of existing norms of the Military Penal Code of Peace and the Military Penal Code of War, although it could be argued that some of them were in fact retroactive, in particular in

\footnotetext{
${ }^{4}$ Expression used by Fronza (n 1$)$.

${ }^{5}$ The High Court of Justice for Sanctions against Fascism (Alta Corte di Giustizia per le Sanzoni contro il Fascismo), the Special Courts of Assize (Corti Straordinarie di Assise) and then the Extraordinary Chambers of the Courts of Assize (Sezioni Speciali delle Corti di Assise).

${ }^{6}$ Battini (n 1); Woller (n 1).

${ }^{7}$ Woller (n 1) 7 .
} 
their application to civilians and in the creation of a legal presumption of guilt for some high-level officials. ${ }^{8}$

The most important aspect of these norms is that they mark an important division of the two paths in criminal prosecution by qualifying as collaborationism (collaborazionismo) crimes committed from the signing of the armistice until the 25th of April, 1945. ${ }^{9}$ This qualification emphasizes the context of war and implicitly denies an autonomous nature of Fascist crimes apart from supporting the enemy. ${ }^{10}$ As we will see, this already begins to pave the way for future memory paths: the increased hiding of Fascist crimes in the shadow of the ones committed by the Nazis.

\section{THE JUdiciary AS THE MAIN ACTOR OF THE ITALIAN TRANSITION}

In order to understand the active role of the judiciary, an important element of this early phase has to be considered, namely the complexity of the lustration of Fascists from the judiciary bodies, considering that the regime had lasted over twenty years. ${ }^{11}$ The lustration was very limited and incomplete, especially in the highest judiciary bodies, because the need of the new political government to avoid direct control and to preserve the independence of the judiciary prevailed. Even if the judges were nostalgic for the regime, the alternative of special tribunals directly organized by the partisans was seen as maintenance of the state of war and a legalized vendetta. The gradual shift from special courts to an ordinary justice system nevertheless explains the increasing role of the judiciary in preventing the punishment of the Fascists.

\footnotetext{
${ }^{8}$ These were introduced with article 1 of the Legislative Decree of the Lieutenant of the Realm of the $22^{\text {nd }}$ of April, $1945 n^{\circ} 142$. On this issue, Vassalli and Sabatini (n 1); Donini ( $n$ 1); Barile and De Siervo (n 1) 548; Piero Calamandrei, 'Nel limbo istituzionale', (1945) 1 Il Ponte 4; Carlo Jemolo, 'Le sanzioni contro il fascismo e la legalità', (1945) 1 Il Ponte 277.

${ }^{9}$ Vis à vis article 5 of the Legislative Decree of the Lieutenant of the Realm of the $27^{\text {th }}$ of July, $1944 \mathrm{n}^{\circ} 159$.

${ }^{10}$ Indeed article 2 of the Legislative Decree of the Lieutenant of the Realm of the $27^{\text {th }}$ of July, $1944 n^{\circ} 159$ did punish the «creation of the Fascist regime» itself and article 3 criminalized the «relevant acts» for its maintenance. Nevertheless, regarding the crime vis à vis article 2 , both the actus reus and the mens rea standards were so high that it was almost impossible to prove them against any accused, but maybe Mussolini. For a detailed analysis of these norms see Donini (n 1) 193; Seminara (n 1) 13.

As for the choice of the crime of collaborationism, there were surely other possible ways in order to punish those who fought for the Italian Social Republic by applying norms already existing in the Military Penal Code of War of 1941. See Franzinelli (n 1) 28; Vassalli and Sabatini (n 1) 24 and 94.

${ }^{11}$ This problem was not limited to the lustration from the judiciary bodies. As Hans Woller explains, «Fascism, in the precise and effective words of Alberto Acquarone, is a regime "that has failed to become totalitarian", mainly because it was never able to untie the knot that in 1922 had formed the alliance with the monarchy, the military and the Church»; also the huge number of party members has to be considered (in 19393.400 .000 out of a population of almost 45 million), Woller (n 1) 9. On the lustration within the judiciary see Antonella Meniconi, Storia della magistratura italiana (Il Mulino 2012); Giovanni Focardi, Magistratura e fascismo: l'amministrazione della giustizia in Veneto 1920-1945 (Marsilio 2012); Giovanni Focardi, 'Le sfumature del nero: sulla defascitizzazione dei magistrati' (2005) 64 Passato e presente 61.
} 
The Legislative Decree of the Lieutenant of the Realm of the $13^{\text {th }}$ September, $1944 \mathrm{n}^{\circ}$ 198, which established the High Court of Justice for Sanctions against Fascism (suppressed in 1945), ${ }^{12}$ affirmed under article 9 that its judgments were to be considered final and no form of appeal was foreseen. Nevertheless, in May 1946, the Supreme Court of Cassation permitted itself to re-examine the decisions of the High Court of Justice and rejected the convictions of prominent leaders of the Fascist regime. This practice was then endorsed, and therefore made clearly legal, by the Constituent Assembly. ${ }^{13}$ This simple episode is a mere example of the gradual transition of the trials from special tribunals (which included not only members of the judiciary, but also citizens appointed by the National Liberation Committee) to the ordinary justice system, where in many cases the trials resulted in impunity.

Many examples of the "activism" of the Supreme Court of Cassation can be given. The legal presumptions of guilt for the crime of collaborationism for some high-level officials for instance, meant as absolute, were interpreted as relative. New excuses, which were not foreseen in the Italian Penal Code, were practically made up, such as the excuse for those who collaborated with the enemy, but with the intention of acting for the good of the nation. ${ }^{14}$ Due to the activism of the Supreme Court of Cassation in rejecting convictions of lower courts, the law in action was different from the law on the books.

Between 1944 and 1949 twenty-four clemency measures were introduced. ${ }^{15}$ In relation to the above mentioned crimes committed by Italian Fascists, the most important was the amnesty decree of the 22nd of June, 1946, $\mathrm{n}^{\circ}$ 4, known as Togliatti amnesty, ${ }^{16}$ issued by Palmiro Togliatti, Minister of Justice and leader of the Communist Party. The amnesty law was introduced just fourteen months after the end of the war.

In the European context, the quick Italian solution appears unique. In France two amnesty laws were issued in 1951 and $1953^{17}$ after about 170.000 trials. In Norway, where out of a population of 3 million, 18.000 were sentenced and 28.000 received financial, administrative or disciplinary sanctions, the amnesty of 1949 was applied only to those who had already served at least a half of their sentence. No amnesty law was introduced in

\footnotetext{
12 The High Court was suppressed in 1947, but from 1945 on it was not a judicial body anymore; its only task was the declaration of ejection from the Senate for senators who had an active role in the regime.

${ }^{13}$ Decree of the Provisionary Head of State of the $17^{\text {th }}$ of May, 1946, n. 494.

${ }^{14}$ Donini (n 1) 210.

${ }^{15}$ For individual clemency measures see Cecilia Nubola, 'I provvedimenti di clemenza nei confronti dei «collaborazionisti» nell’Italia del secondo dopoguerra. Un esempio di giustizia di transizione' in Heinz-Gerhard Haupt and Paolo Pombeni (eds), La transizione come problema storiografico. Le fasi critiche dello sviluppo della «Modernità» (1494-1973) (Il Mulino 2013) 319; Cecilia Nubola 'Giustizia, perdono, oblio. La grazia in Italia dall'età moderna ad oggi’ in Karl Härter and Cecilia Nubola (eds), Grazia e giustizia (Il Mulino 2011) 39.

${ }^{16}$ Franzinelli (n 1), Vassalli and Sabatini (n 1).

${ }^{17}$ Another amnesty had been issued in 1947, but it concerned just minors and public workers who had received very minimal disciplinary sanctions. On this issue Franzinelli (n 1) 253, Battini (n 1) 129.
} 
Belgium, the Netherlands or Luxembourg, while in Austria amnesty was only issued in $1948 .^{18}$

Presented as an instrument in the interest of political pacification, amnesty was the result of both national and international pressure. Amnesty was not meant to be general and had some important exceptions, but the very indeterminate formulas contained in the text permitted the highest degree of discretionary power. With the telegraphic directive n. 9809/110/6 Gab. issued on the 10th of July, 1946, titled Application of the amnesty in favour of partisans, Togliatti recommended to the judiciary to also apply the amnesty in favour of the partisans. This case clearly indicates the attitude of the judiciary. Even a directive of the Minister of Justice was required, in order to remind them that the amnesty was not meant only for the Fascists. The tendency of the judiciary can also be clearly read between the lines of a previous telegraphic directive of the Minister, n. 9896/110, issued on the $2^{\text {nd }}$ of July, 1946, titled Amnesty for Fascist crimes, where Togliatti asks for an application of the amnesty law in coherence with the spirit given to it by the legislator, who "wanted the punishment of Fascist perpetrators to continue". ${ }^{19}$

In spite of these interventions, the result was a widespread application in favour of the Fascist criminals. The interpretation given by the Supreme Court of Cassation nullified in practice the constraints which hindered the application of the amnesty. In the Italian judicial system, the Supreme Court of Cassation cannot overrule the trial court's interpretation of the evidence, but it can only verify and correct a lower court's interpretation or application of the law connected to a specific case. Therefore, when it was impossible to reject the former conviction on the basis of the interpretation of the law, the Supreme Court of Cassation often used its power to require a retrial at a different Appeal Court of Assize, geographically distant from the place where the alleged criminal acts occurred (often at the Appeal Court of Assize in Perugia, which was known for being very "generous" when acquitting the accused and accepting doubtful interpretations of the evidence). This resulted in an almost total paralysis of the proceedings against Italians for the crime of collaborationism: 23.000 indicted collaborationists benefited from the amnesty during the trial and 5.328 convicted collaborations (from a total amount of 5.928) were acquitted. It is important to remember that among them were also people who had made an important ideological or practical contribution to the persecution and deportation of Jews to the extermination camps.

In its practical application, the Togliatti Amnesty resulted in a moral "rehabilitation of Fascism". ${ }^{20}$ In most cases it was applied in the trials before the conviction, resulting also in a deprivation of the truth-finding role of the prosecution. Furthermore, in order to assure the application of amnesty even to perpetrators of those crimes for which it should have been inapplicable, the judiciary manipulated the facts or interpreted them in an inconsistent and arbitrary way. In order to acquit the accused, many times the result was an implicit rehabilitation of Fascism.

\footnotetext{
${ }^{18}$ Franzinelli (n 1) $253-259$.

${ }^{19}$ For a disapproving comment on the use of these directives, see Ugo Pioletti, 'Osservazioni sul decreto di amnistia 22 giugno 1946, n. 4’ (1946) 1 Archivio Penale 471, 473.

${ }^{20}$ Franzinelli (n 1) 259.
} 
In 1948, public workers who had been dismissed after a conviction for collaborationism could be reinstated to their post, and received payments for the wage loss and the equivalent salary pension. Almost every appeal lodged with ordinary or military courts during the 1950s resulted in the reinstatement of workers and no expression of repentance was required by the judiciary bodies. On the contrary, while once again rehabilitating the dignity of the single person, the judiciary implicitly minimized the crimes committed by the Fascist regime and furthermore tried to accentuate positive moral qualities of the perpetrators, such as attachment to family, religion and the homeland. Even those who at the time were already dead, and even those who had been executed on the basis of a conviction, could benefit from this rehabilitation through an appeal submitted by the heirs of the deceased. Among them, were many important hierarchs of the Italian Social Republic who were reinstated to their previous military rank. The political scenario of the $1950 \mathrm{~s}$ was characterized by a fear of Communism, in the light of the Cold War. From 1948 on, the Communist Party was no longer part of the government. At the same time, many criminal and civil lawsuits against partisans were filed and the judiciary was very strict in the application of amnesty in their favour. ${ }^{21}$

The aforementioned explanation could nevertheless be deceptive, if it leads to the conclusion that the judiciary, and in particular the Supreme Court of Cassation, was the only party responsible for the described path towards impunity for Fascist crimes. This conclusion would be too simplistic, although it was used by Togliatti himself, when the idea of amnesty as an instrument of national reconciliation was no longer considered sustainable by public opinion. ${ }^{22}$ In late September, 1946, Togliatti affirmed that the judiciary managed to reach its aim "violating the law, or better applying the law in their own way." He also admitted that this attitude was foreseeable, but "it was impossible to act differently in a democratic bourgeois regime; only in a more advanced democracy could we have acted differently." 23 This seems to be an easy and self-acquitting answer for the ruling class.

It must be remembered that the described application of amnesty in favour of the Fascist criminals was possible because the wording of the amnesty law was ambiguous and imprecise. Furthermore, amnesty did not provide any distinction between the treatment of those responsible for actions punishable with a few years of detention, and with up to thirty years, or even

\footnotetext{
${ }^{21}$ In fact article 3 of the Togliatti amnesty, which applied to the Fascists, included also the crimes connected to the crime of collaborationism and the crime of relevant acts for the maintenance of the Fascist regime, whereas for the "crimes connected" committed by the partisans, the application of amnesties was more complicated, since there was not a specific political crime created for all of their actions; therefore a specific pardon had to be issued in 1953. In this regard, see Amedeo Santosuosso and Floriana Colao, Politici e amnistia. Tecniche di rinuncia alla pena per i reati politici dall'unità ad oggi (Bertani 1986)., 123; Mario Pittalunga, 'Rilievi sul decreto di amnistia e di indulto del 9 febbraio 1948, n. 32. (Una delusione)' (1948) Archivio Penale 108.

${ }^{22}$ In this regard, Giorgio Almirante, head of the cabinet of the Ministry of Culture in the Italian Social Republic and future leader of the Italian Social Movement (MSI), a post-fascist rightist political party, wrote «the instrumental aim of the amnesty was clear from the beginning; it did not aim to pacify, but to absorb low-level, and sometimes also high-level Fascists». Franzinelli (n 1) 138.

${ }^{23}$ See Franzinelli (n 1) 120.
} 
life imprisonment. Depending on the application (or not) of an amnesty, the outcome was extremely variable: punishment on one hand, and obliteration of all legal remembrance of the offence on the other. Preventing no partial solution, and knowing that the judiciary could be sympathetic to the accused for political reasons, a stretching of legality in favour of impunity could have been foreseeable. Nevertheless, the amnesty law deliberately conferred significant discretionary power to the judiciary in relation to very delicate issues, for which the legislator should have taken more responsibility. An important example is article 3 of the amnesty law, which excludes the application of amnesty in favour of those who served "high-level functions of civilian, political or military direction." It is easy to understand the vagueness of this parameter, which was meant for very different entities, such as the governmental, administrative and military sectors of Italy (which in fact for twenty years corresponded to the Fascist regime), the internal structure of the Fascist political movement, the administrative, governmental, military and judicial structure of the Italian Social Republic, the Fascist paramilitary groups, and the members of private enterprises. No guidelines were provided for the interpretation of such criterion, the application of which (or not) resulted in the aforementioned extreme variance between impunity and (possibly very severe) punishment. Everything was left in the hands of the judiciary, which highlights an intrinsic contradiction of the amnesty law and therefore a corresponding loophole. ${ }^{24}$

Article 3, as mentioned above, was the parameter for the nonapplication of amnesty to the crime of relevant acts for the maintenance of the Fascist regime and to the crime of collaborationism. The resolving criterion to decide between punishment and impunity was the qualification of the crimes as facts of massacre, particularly cruel brutality, murder or pillage, or that the crimes be committed with the purpose of obtaining profit. If indeed the role of the Court of Cassation in stretching the interpretation of those terms cannot be denied, "it is equally beyond doubt that it was the legislator itself, which had introduced the distinction between "cruel brutality" and "particularly cruel brutality" - and it was on that basis that - the Court of Cassation drew, at the extreme limit of what the human mind is capable of devising, a border." ${ }^{25}$ In fact the legislator had just formulated the concept of particularly cruel brutality, without giving any definition and this allowed the judiciary to affirm that the legislator had introduced a triple distinction between brutality, cruel brutality and particularly cruel brutality and only the last one would be excluded from the application of amnesty. Gang rape, de-nailing and similar practices were considered normal torture or cruel brutality, since for the brutality to be "particularly cruel" it was required that it would "horrify even those who are familiar with torture."26

\footnotetext{
${ }^{24}$ The argument was the following: if the criterion of the high-level functions of civilian, political or military direction should be applied strictly, it would be in contradiction with the fact that this criterion applies also to the crime of relevant acts for the maintenance of the Fascist regime, which implicitly requires the perpetrator to be, in order to be able to commit relevant acts for the maintenance of the regime, a high-level hierarch. On this issue Franzinelli (n 1) 157, Donini (n 1) 209.

${ }^{25}$ Woller (n 1) 546. He adds: "It appears improper to speak of a great conspiracy of the Cassation, which intended to hinder the punishment of Fascist crimes. A mixture of abuses should rather be considered" Woller (n 1) 547.

${ }^{26}$ Donini (n 1) 210; Barile and De Siervo (n 1) 552; Galante Garrone (n 1) 1064.
} 
With regard to other issues, the text of the amnesty law is less to blame and the responsibility of the judiciary is more apparent. Amnesty, for instance, was excluded for facts of ... pillage, but the judiciary read it as crime of pillage, a crime that in the Italian Penal Code is an offence against public order and therefore amnesty was applied every time the pillage did not offend the public order, understood to be the Nazi occupying power and the Italian Social Republic, which in fact could never be offended by a pillage committed by Fascists themselves. ${ }^{27}$ Some of the accused, who had served as judges in the tribunals of the Italian Social Republic, were acquitted by applying the putative justification of acting in the fulfilment of a duty, although that duty derived from the Italian Social Republic and the legislator had affirmed, with the Legislative Decree of the Lieutenant of the Realm October 5, 1944 n. 249, that every act, provision, decision or judgment rendered by the self-styled government of the Italian Social Republic or its institutions had to be considered unlawful and lacking any juridical effect. The judiciary also applied amnesty to a large number of cases of murder on the basis of a lack of intent, forgetting that the Italian Penal Code provides criminal responsibility even for the perpetrator who intended to commit a different crime (article 83), or for the accomplice who did not intend to commit the specific crime committed by the main perpetrator (article 116). ${ }^{28}$ This mechanism was used for the death of anti-fascists in the context of punitive expeditions of the paramilitary groups Camice Nere, for the death of partisans in anti-partisan sweeps and even for executions by firing squad, when evidence proved that the accused was present in the squad, but not that he was actually one of those who shot. ${ }^{29}$

Even before amnesty, the norms introduced for the punishment of Fascist crimes were reluctant to explicitly criminalize the conduct of the Fascists when they were not considered an advantageous contribution to the Nazi enemy. The concept of collaborationism nonetheless is a concept that fits better to other European occupied countries, ${ }^{30}$ not to Italy, where a dictatorship was present even before the birth of the Third Reich and was responsible of autonomous and terrible crimes. This nascent hesitation resulted in the first division of the previously described double path.

There is nevertheless a group of Fascist crimes, where the the role of the government in order to obtain impunity was incomparably more important and less ambiguous: crimes committed abroad. In fact, the Powers Pact of 1940 was meant as a division of the world into spheres of interest and "in justifying the occupation of their neighbouring countries, all three powers were, albeit to a different extent, motivated by a concept of the supremacy of

\footnotetext{
${ }^{27}$ Barile and De Siervo (n 1) 552; Franzinelli (n 1) 228; Vassalli and Sabatini (n 1) 547.

${ }^{28}$ Donini (n 1) 211.

${ }^{29}$ Franzinelli (n 1) 224 - 228.

${ }^{30}$ For the evolution of this concept in the context of the Second World War, see Jan T. Gross, 'Themes for a Social History of War Experience and Collaboration', in István Deák, Jan T. Gross, Tony Judt (eds), The Politics of Retribution in Europe: World War II and its Aftermath (Princeton University Press 2000), 15. See also Jean-Paul Sartre, 'Qu'est-ce qu'un collaborateur?' (1945) La République Française 14.
} 
their own race." "I1 "Italy fits into this framework to a much lesser extent, as it was limited to Northern Africa, the Balkans and Greece, but it did involve the imposition of many violent forms of control and repression." 32 The long political and diplomatic path which the Italian government (with no dissenting position of this or that political party, or of any minority) followed to not extradite Italian war criminals to Greece, Yugoslavia, Albania or the African colonies, will not be resumed. It is sufficient to describe the clear and simple outcome: not only were none of these people extradited, at the same time no Italian citizen has ever faced a trial in Italy for war crimes committed abroad, and therefore, simply, Italy itself never became conscious of its own responsibilities in these countries. These crimes were simply forgotten. ${ }^{33}$

\section{The Italian Memory Paths in the Aftermath of The ACTIVISM OF THE JUDICIARY}

During the Cold War, and at least from the 1960s onwards, there was a formal recognition of Anti-Fascism and of the role of the Resistance. However, this official memory appeared to be turned into a consecration of legality in defence of public institutions and of the status quo against leftwing and right-wing terrorism. According to the official recognition, Italy did not have a shared memory. The memories of Fascism and Anti-Fascism were based on the different ideological backgrounds. ${ }^{34}$ This resulted in a sharp division between accepting and not accepting the myth of the heroism of the Resistance. This clearly divisive memory is unsurprising, since the concepts of Fascism and Anti-Fascism were still very much alive in the Italian society of the 1960s and 1970s.

After 1989, Italy, as many other countries, underwent a political transition, which occurred between 1992 and 1994. This is commonly known as the transition from the First to the Second Italian Republic. With the end of the former ideologically divisive structure, it would not have been odd if Italy had chosen to put the Togliatti Amnesty into question and to face a real transitional process. Italy could have chosen to endorse a transitional mechanism to even deal with the recent (the so called Years of Lead, Anni di Piombo) ${ }^{35}$ and the most recent past (the corruption system which

\footnotetext{
${ }^{31}$ Kerstin Von Lingen, Nuremberg, Rome, Tokyo: The Impact of Allied War Crimes Trials on Post-War Memory and Identity in Germany, Italy and Japan after 1945 (ESRI 2009).

32 ibid 12. She adds: «in Yugoslavia, up to 200,000 people were murdered, in Greece the Italian occupation cost 100,000 lives, and the occupation period in Northern Africa led to a final total 60,000 victims, executed in a series of massacres of civilians, or during the gas experiments of the Fascist army, a deed which clearly constitutes a war crime».

${ }^{33}$ Filippo Focardi and Lutz Klinkhammer, 'The question of Fascist Italy's war crimes: the construction of a self-acquitting myth (1943 - 1948)' (2004) 93 Journal of Modern Italian Studies 330; Filippo Focardi, 'I mancati processi ai criminali di guerra italiani' in Luca Baldissara and Paolo Pezzino (eds), Giudicare e punire (L'ancora del Mediterraneo 2005); Angelo Del Boca, Italiani brava gente? (Neri Pozza 2005).

${ }^{34}$ Giovanni De Luna, La Repubblica del dolore. Le memorie di un'Italia divisa (Feltrinelli 2011) 169.

${ }^{35}$ This expression refers to a period of socio-political turmoil that lasted from the early $1960 \mathrm{~s}$ into the early 1980s, marked by a way of terrorism of opposing extremisms (left-wing and right-wing terrorism, with the involvement of parts of the intelligence service).
} 
characterized the First Republic) ${ }^{36}$ However, none of these choices was made. Concerning white collar crimes, the responsibility of dealing with the past was left to the judiciary in the so called Mani Pulite (Clean Hands) era. "The image of a strong judiciary without stain or fear, prepared to strike down the old political system contrasted with its chronic inefficiencies, which risked stripping it of the legitimacy that it had so quickly achieved, and revealed the judiciary as a giant with feet of clay;", 37 again historians and political scientists write about this period as an unfinished, ${ }^{38}$ infinite, ${ }^{39}$ neverending transition ${ }^{40}$ or a transition that never was. ${ }^{41}$

It seems possible to draft an Italian approach to political transitions where even public acts of remembrance "appear to have taken on a peculiar meaning: remembering refers not to the need to remember the violent conflict with its publicly recognized, (judicially) assessed, truth(s) as regards victims and perpetrators; rather it refers to the need to remember what is not yet known or properly acknowledged." 42 History is apparently repeating, with retributive justice demonstrating its limits not only in punishing, but also in building a narrative of the event (especially with regards to the so-called stragismo $^{43}$ in the face of episodes of obstruction on the part of the intelligence services) and the failure to reach a political consensus over the need for a non-judicial process of truth telling, apart from formal acts of remembrance. ${ }^{44}$

At the same time, while transitioning from the First to the Second Republic, Italy faced the crisis of the welfare state, in which the Italian Constitution is deeply connected to the values of Anti-Fascism. The whole process led to a crisis of the former official memorial paradigm and influenced historical revisionism of the role of Resistance. ${ }^{45}$ Yet, in the new

\footnotetext{
36 On this topic, Guido Bertagna, Adolfo Ceretti and Claudia Mazzuccato, Il libro dell'incontro (Il Saggiatore 2015).

${ }^{37}$ Stefano Anastasia, 'From the bottom of the bottle: justice, prison and social control in the Italian transition' (2015) 202 Journal of Modern Italian Studies 213.

${ }^{38}$ Umberto Gentiloni Silveri, 'Italy's unfinished transition: between domestic dynamics and international change' (2015) 202 Journal of Modern Italian Studies 189.

${ }^{39}$ Gianfranco Pasquino, 'Teorie della transizione e analisi del sistema politico: il caso italiano' (2001) 2 Rivista Italiana di Scienza Politica 313.

${ }^{40}$ Anna Cento Bull, 'The Italian transition and national (non)reconciliation' (2008) 133 Journal of Modern Italian Studies 405.

${ }^{41}$ Martin J. Bull, 'The Italian transition that never was', (2012) 171 Modern Italy 103; see also James L. Newell, 'The man who never was? The Italian transition and 2008 election' (2009) 144 Journal of Modern Italian Studies 395.

42 Cento Bull (n 40) 410.

43 This umbrella term is used mainly among journalists in order to describe a group of bombing attacks, committed between the ' $60 \mathrm{~s}$ and the ' 70 s by right-wing and neo-fascist paramilitary groups with collaboration of members of the intelligence service, following the logic of the strategy of tension, which means in order to manipulate the public opinion and the votes, by generating the impression of a national threat.

${ }^{44}$ «The only consensus for some form of restorative justice seems to be around the need to establish official Days of Remembrance [...] but did not extend to a process of truth telling». Cento Bull (n 40) 415. «In short, there is a risk that Italy repeats the path followed after the Second World War, when the fascist war crimes, the civil war and the Resistance were dealt with through amnesia and amnesty, accompanied by formal acts of remembrance». Ibid 417 . ${ }^{45}$ This phenomenon happened not only among historians, but also in the media and in the wider public debate. Examples of this can be found in a second wave of litigation over the
} 
Italian political scenario from 1994 to 2011, Silvio Berlusconi portrayed his political figure both as a reaction to the former memorial paradigm and, at the same time, as a bastion against the power of the judiciary in the Clean Hands investigations.

Nevertheless, going back to the transition from the Second World War, something did indeed change in the 1990s, mainly concerning the punishment of Nazi criminals. ${ }^{46}$ The trials of Nazi officers before Italian military courts had numbered less than twenty in 1960, when the General Military Prosecutor arbitrarily decided on the provisional dismissal of the proceedings due to internal and international pressure. This standstill ended in 1994, with the discovery of the so called armoire of shame (armadio della vergogna): ${ }^{47}$ an archive of 695 files documenting war crimes. This controversial discovery led to the opening of two Commissions of Inquiry (one of the Council of the Military Judiciary and one of the Italian Parliament ${ }^{48}$ and resulted in a new judicial phase, with trials in absentia against (old) Germans accused by the military courts 50 years after the alleged

facts of the bomb attack in Via Rasella and of the Ardeatine Caves Massacre between 1999 and 2007. On this important episode of Italian history see Giorgio Resta, and Vincenzo ZenoZencovich, "Judicial "Truth" and Historical "Truth": The Case of the Ardeatine Caves Massacre' (2013) 314 Law and History Review 845.

The above described phenomenon also led to two bills, which were proposed (but not adopted) in 2004 (XIV Legislatura, Senato della Repubblica, Disegno di legge n. 2244) and 2008 (XVI Legislatura, Camera dei Deputati, Proposta di Legge n. 1360). These bills intended to qualify as "lawful combatants" the soldiers, petty officers and officers who served for the Italian Social Republic and to grant them the same legal status of those who fought as partisans and those who fought in the Italian army, both in terms of decorations and life annuity. On this topic Filippo Focardi, 'Rielaborare il passato. Usi pubblici della storia e della memoria in Italia dopo la Prima Repubblica' in Giorgio Resta and Vincenzo Zeno-Zencovich (eds), Riparare, risarcire, ricordare. Un dialogo tra storici e giuristi (Editoriale scientifica 2012).

${ }^{46}$ This is what we have called the second path of criminal prosecution, which refers to the Germans. After an early phase of few criminal trials before military tribunals, their criminal prosecution stopped in 1960 and started again after 1994. For an overview of the history of criminal prosecution of Nazi officers in Italy, see Silvia Buzzelli, Marco De Paolis, Andrea Speranzoni, La ricostruzione giudiziale dei crimini nazifascisti in Italia (Giappichelli 2012); Filippo Focardi, 'La questione dei processi ai criminali di guerra tedeschi in Italia: fra punizione frenata, insabbiamento di Stato, giustizia tardiva (1943-2005)', in Norbert Frei (ed), Transnationale Vergangenheitspolitik. Der Umgang mit deutschen Kriegsverbrechern in Europa nach dem Zweiten Weltkrieg (Wallstein 2006); Resta and Zeno-Zencovich (eds), Riparare, risarcire, ricordare (n 45).

47 The armoire of shame was a wooden cabinet discovered in 1994 inside a large storage room in Palazzo Cesi-Gaddi in Rome which, at the time, housed the chancellery of the military attorney's office. The cabinet contained an archive of 695 files documenting war crimes perpetrated on Italian soil during the Nazi occupation. It remains unclear, to this day, how the archive remained concealed for so long, and who gave the order to hide the files in the immediate post-war period. On this issue, see Franco Giustolisi, L'armadio della vergogna (Nutrimenti 2004).

48 The Commision of Inquiry of the Italian Parliament delivered a majority and a minority report: Commissione parlamentare di Inchiesta sulle cause di occultamento dei crimini nazifascisti, Relazione Finale, XIV Legislatura, Doc. XXIII, n. 18, available at http://www.senato.it/service/PDF/PDFServer/BGT/301476.pdf Approvazione 8.02.2006; Commissione parlamentare di Inchiesta sulle cause di occultamento dei crimini nazifascisti, Relazione di Minoranza, XIV Legislatura, Doc. XXIII, n. 18-bis, Presentazione 24.01.2006, available at http://www.senato.it/service/PDF/PDFServer/BGT/203175.pdf. 
criminal acts. For the first time in the history of the Italian military criminal system, victims and historians were also highly involved. ${ }^{49}$

In the same years the memory of a particular segment of the Second World War changed: the memory of the Shoah. New victim-centric tendencies emerged in connection to a broader commemorative trend, which affects not only Italy. On the basis of this commemorative impetus, the law and criminal trials have become the primary instrument for protecting and constructing memory and in particular the memory of the Shoah, which is presented as a unique episode so terrible as to be considered somehow out of the realm of human history itself. ${ }^{50}$ In the light of this new perspective on historical events, memory appears to be absorbing the complexity of the past. A clear example can be found in the Italian law $n^{\circ} 4557$ of 2000, which introduces the Shoah Remembrance Day and never mentions the word Fascism. Contrary to an original proposition, the Shoah Remembrance Day was set on the day of the liberation of Auschwitz and not on the day of the deportation of the Jews from the Roman Ghetto, an event which would have implied a major recognition of Italian responsibilities in the Shoah (with the introduction of the Racial Laws, the anti-Semitic public propaganda and the concrete collaboration with the Nazis in the deportations.) ${ }^{51}$ This tendency was confirmed by the introduction of the crime of denialism "of the Shoah" in June 2016.

\section{FINAL REMARKS}

After the war, the national identity was built on the myth of AntiFascism and on the idea that the dead martyrs of the Resistance, the people of the dead, ${ }^{52}$ demanded a new democratic order so that their deaths would not be considered in vain. The vision, even within the Resistance, was indeed more forward- than backward-looking. In recent years, the memorial paradigm has changed. The new paradigm is illustrated by the actual narrative of the Shoah, which emerges from the official Italian remembrance: a commemoration of a tragedy totally cut off from Italian society itself. ${ }^{53}$

\footnotetext{
${ }^{49}$ On this issue see Andrea Speranzoni, in Buzzelli and De Paolis and Speranzoni (n 46) 159, Paolo Pezzino, 'Lo storico come consulente', in Resta and Zeno-Zencovich (eds), Riparare, risarcire, ricordare (n 45) 83.

${ }^{50} \mathrm{On}$ this topic in the Italian scholarship Enzo Traverso, Il passato: istruzioni per l'uso. Storia, memoria, politica (Ombre Corte 2006); Emanuela Fronza, Il negazionismo come reato (Giuffrè 2012).

${ }^{51}$ See Andrea Pugiotto, 'Quando (e perché) la memoria nazionale si fa legge' in Andrea Pugiotto (ed), Per una consapevole cultura costituzionale. Lezioni magistrali (Jovene 2013). 52 Expression used by Piero Calamandrei at the Constituent Assembly, in his intervention on the $4^{\text {th }}$ of March 1947. See Lorenzo Paggi, Il «popolo dei morti» (il Mulino 2009) 233.

${ }^{53}$ In this regard it is very intriguing to change the point of view and see how the relationship between Italy and the Shoah is seen abroad, since immediately after the war the Italian government was engaged in intense efforts to present the Italian people as saviors of Jews in the eyes of the international community. It is extremely interesting to read the saviour narrative of those events, which visitors can find at the Yad Vashem in Jerusalem, Israel's official museum and memorial to the victims of the Holocaust: "In 1938 Fascist Italy passed racist, anti-Semitic laws that severely harmed the Jews in all areas of life. Nonetheless, from
} 
Italians have to remember and to commemorate a terrible and unique tragedy, which seems to have happened long ago and far away in an undefined place and time, instead of just a few decades ago. In the new commemorative scenario of Jewish victims, history is reduced to the biographical narrative of the memory of the single victim, whereas the understanding of the broader background and the figure of the perpetrator is in fact not important for the commemorative aim. ${ }^{54}$ With this new attitude, the historical context of the involvement of Italian Society, of Fascism and Anti-Fascism are useless and in fact disappear. In the light of the unique tragedy of the Shoah and the sacrifice of the innocent Jews, every other aspect of the Second World War seems to be doomed to the shadows. In a weird historical evolution, an old idea emerges, the same idea which can be implicitly or explicitly traced back through the very first stage of the Italian transition from the Second World War: the idea that war crimes, even massacres, are part of the fate of wartime and can somehow be understood or justified in that context. ${ }^{55}$ The roots of this evolution can be traced back to the process described previously. This last recent stage completes a process of social de-responsibilization of the Italian society.

Besides the criminal prosecution of Fascist criminals, the work of the judiciary had a significant impact on the collective memory of those events. The different experiences of the many waves of transitional justice have taught that a criminal trial should not be asked to pursue aims that go beyond its natural purpose to determine the criminal responsibility of an individual on the basis of given provisions and procedural rules. In particular, criminal judges should not be asked to fulfil social demands for reliable and impartial truth about past historical events, as if judges had the means and the authority to write down a final narrative of national history, once and for all. Yet it cannot be denied that criminal trials do indeed provide a fragmentation of truth. This may not be as comprehensive or analytical as the work of historians, but indeed it can be a very important basis for the building of a collective memory, especially if no other non-judicial mechanism is chosen in that particular transitional context. From this perspective, an evaluation of the Italian transition cannot be reduced to the simplistic consideration that the judiciary is to be blamed, and the ruling class is not to be held responsible at all. Not only can it be said that "the legislative programme of the years 19441945 failed because of both the legislator itself and of the judiciary, ${ }^{, 56}$ but moreover both after the War and in the 1990s, the legislator acted ambiguously and did not have the courage and the strength to deal with a past,

1941 - 194, in the territories under Italian control in Yugoslavia, Greece and France, members of the Italian Army and the Foreign Ministry took measures to save Jewish lives for political and humanitarian reasons. In Italy itself, the government did not allow deportation of Jews through September 1943. When the Germans then took over Italy, the fascist regime participated in the deportation of Jews for extermination and in the looting of their property. While Jews were being handed over, many other Italians, in particular priests and nuns, helped Jews find hiding places. Owing to this help and the possibilities of fleeing to Switzerland, along with the Allied invasion, about $80 \%$ of Italian Jewry were saved". On the efforts of the Italian government to present the Italian people as saviour of Jews in the eyes of the international community, see Filippo Focardi, Il cattivo tedesco e il bravo italiano (n 2) 113

${ }^{54}$ Giovanni De Luna (n 34) 149.

${ }^{55}$ Michele Battini (n 1).

${ }^{56}$ Donini (n 1) 200. 
which seems doomed to remain present and unsolved. In this, it is possible to find a constant element of Italian society facing its two never-ending transitions, which can partly be explained with a characteristic trait of Italian society: the incompiuto (incompleteness) of every political change. This has been poetically summed up by novelist Giuseppe Tomasi di Lampedusa in The Leopard: "Everything needs to change, so everything can stay the same." That constant element is the shouting silence of the ruling class, which did not demonstrate the strength or the interest in facing a real transitional process, not necessarily through criminal proceedings and not necessarily in the immediate aftermath of the war.

Discussing the trials related to the so called Years of Lead and the strategy of tension, the intellectual Pier Paolo Pasolini wrote

"Why is everything still as in a cemetery? It is frighteningly clear.

Because all these investigations and trials, once they are brought to an end, would lead to nothing but the Trial of which I speak. [...] the Criminal Trial of which I speak has (in my imagination as a moralist) the shape, the meaning and the value of a synthesis. [...] If the conscious desire to know of the Italian citizens does not have the strength to force the power to take off its mask, to self-criticize [...], this means that we are a very poor country: indeed, let us say, a miserable country." $" 57$

It seems that, with regards to the transition from Fascism, Italy did not only lose the opportunity to punish those responsible for serious crimes. Apparently Italy has also lost the chance to deal with its own dictatorial past and to reunite the Italian people not on the basis of forgetting, but instead by constructing an inclusive collective memory. More importantly, Italy could have developed consciousness of the crimes committed within its society and by its own governmental institutions. This could have constituted an important occasion to generally meditate on the vulnerability of the present democratic order and on the impact of ideology on individuals, which represents, as Hannah Arendt made clear, the moral problem of evil.

It can certainly be argued that the situations after the war and in the 1990s were different, as the legislator chose different instruments to deal with the transitions. In 1946, the (ambiguous) amnesty law was introduced, whereas in fact nothing was done in the 1990s (in 1993 an attempt to introduce a retroactive decriminalization of illegal funding to political parties was abandoned.) $)^{58}$ Nevertheless it is still possible to affirm that in both cases, in spite of the differences, a common attitude seems to influence the different instruments chosen. The impression is that both transitions resulted in an explicit or implicit abdication of the legislator from its political role, while politics seemed to prefer to leave discretion and responsibility to the judiciary. This led to a situation where, in fact, the judiciary was probably, both in the

\footnotetext{
${ }^{57}$ Pier Paolo Pasolini, 'Perché il processo' Corriere della Sera (Milano, 28th September 1975).

58 The so called decree-law "Conso-Amato" of the $5^{\text {th }}$ of March, 1993 did not obtain the absent of the President of the Republic, Oscar Luigi Scalfaro, which is required to sign the decree into law.
} 
1940s and in the 1990s, for better or for worse, the main (explicit) actor of the incomplete Italian transitions.

\section{References}

Anastasia S, 'From the bottom of the bottle: justice, prison and social control in the Italian transition' (2015) 202 Journal of Modern Italian Studies

Barile P, De Siervo U, 'Le sanzioni contro il fascismo e il neofascismo' (1969) XVI NSSDI

Battaglia A, I giudici e la politica (Laterza 1962)

Battini M, La mancata Norimberga italiana (Laterza 2003)

Bertagna G, Ceretti A, Mazzuccato C, Il libro dell'incontro (Il Saggiatore 2015)

Bull MJ, 'The Italian transition that never was', (2012) 171 Modern Italy 103

Buzzelli S, Paolis M, Speranzoni A, La ricostruzione giudiziale dei crimini nazifascisti in Italia (Giappichelli 2012)

Calamandrei P, 'Nel limbo istituzionale', (1945) 1 Il Ponte

Calamandrei P, 'Restaurazione clandestina', (1947) 3 Il Ponte

Canosa R, La storia dell'epurazione in Italia: le sanzioni contro il fascismo 1943-1948 (Baldini \& Castoldi 1999)

Cento Bull A, 'The Italian transition and national (non)reconciliation' (2008) 133 Journal of Modern Italian Studies

Commissione parlamentare di Inchiesta sulle cause di occultamento dei crimini nazifascisti, Relazione Finale, XIV Legislatura, Doc. XXIII, n. 18, Approvazione 8.02.2006

Commissione parlamentare di Inchiesta sulle cause di occultamento dei crimini nazifascisti, Relazione di Minoranza, XIV Legislatura, Doc. XXIII, n. 18-bis, Presentazione 24.01.2006

Deakin FW, The Brutal Friendship. Mussolini, Hitler and the fall of Italian Fascism (Harper and Row 1962)

De Luna G, La Repubblica del dolore. Le memorie di un'Italia divisa (Feltrinelli 2011)

Del Boca A, Italiani brava gente? (Neri Pozza 2005)

Donini M, 'La gestione penale del passaggio dal fascismo alla Repubblica in Italia' (2009) XXXIX 1 Materiali per una storia della cultura giuridica

Focardi F, 'I mancati processi ai criminali di guerra italiani' in Baldissara L, Pezzino P (eds), Giudicare e punire (L'ancora del Mediterraneo 2005)

Focardi F, Il cattivo Tedesco e il bravo italiano (Laterza 2014)

Focardi F, 'La questione dei processi ai criminali di guerra tedeschi in Italia: fra punizione frenata, insabbiamento di Stato, giustizia tardiva (1943-2005)', in Frei N (ed), Transnationale Vergangenheitspolitik. Der Umgang mit deutschen Kriegsverbrechern in Europa nach dem Zweiten Weltkrieg (Wallstein 2006) 
Focardi F, Klinkhammer L, 'The question of Fascist Italy's war crimes: the construction of a self-acquitting myth (1943 - 1948)' (2004) 9 3 Journal of Modern Italian Studies

Focardi G, Magistratura e fascismo: l'amministrazione della giustizia in Veneto 1920-1945 (Marsilio 2012)

Focardi G, 'Le sfumature del nero: sulla defascitizzazione dei magistrati' (2005) 64 Passato e presente

Focardi G, Nubola C, Nei tribunali. Figure della clemenza fra tardo medioevo ed età contemporanea (Il Mulino 2015)

Fornasari G, Giustizia di transizione e diritto penale (Giappichelli 2013)

Franzinelli M, L'amnistia Togliatti. 22 giugno 1946. Colpo di spugna sui crimini fascisti (Mondadori 2006)

Fronza E, Il negazionismo come reato (Giuffrè 2012)

Fronza E, 'La persecución de los crímenes nazi-fascistas en Italia', (2011) 93 Revista Brasilieira de Ciencias Criminais

Galante Garrone C, 'Guerra di liberazione (dalle galere)', (1947) 3 Il Ponte

Gentiloni Silveri U, 'Italy's unfinished transition: between domestic dynamics and international change' (2015) 202 Journal of Modern Italian Studies

Giustolisi F, L'armadio della vergogna (Nutrimenti 2004)

Gross JT, 'Themes for a Social History of War Experience and Collaboration', in István Deák, Jan T. Gross, Tony Judt (eds), The Politics of Retribution in Europe: World War II and its Aftermath (Princeton University Press 2000)

Jemolo C, 'Le sanzioni contro il fascismo e la legalità', (1945) 1 Il Ponte 277

Meniconi A, Storia della magistratura italiana (Il Mulino 2012)

Neppi Modona G (ed), Giustizia penale e guerra di liberazione (Franco Angeli 1984)

Newell JL, 'The man who never was? The Italian transition and 2008 election' (2009) 144 Journal of Modern Italian Studies

Nubola C, 'I provvedimenti di clemenza nei confronti dei «collaborazionisti» nell'Italia del secondo dopoguerra. Un esempio di giustizia di transizione' in Haupt HG, Pombeni P (eds), La transizione come problema storiografico. Le fasi critiche dello sviluppo della «Modernità» (1494-1973) (Il Mulino 2013)

Nubola C, 'Giustizia, perdono, oblio. La grazia in Italia dall'età moderna ad oggi' in Härter K, Nubola C (eds), Grazia e giustizia (Il Mulino 2011)

Paggi L, Il «popolo dei morti» (il Mulino 2009)

Pasolini PP, 'Perché il processo' Corriere della Sera (Milano, 28th September 1975)

Pasquino G, 'Teorie della transizione e analisi del sistema politico: il caso italiano' (2001) 2 Rivista Italiana di Scienza Politica

Pioletti U, 'Osservazioni sul decreto di amnistia 22 giugno 1946, n. 4' (1946) 1 Archivio Penale

Pittalunga M, 'Rilievi sul decreto di amnistia e di indulto del 9 febbraio 1948, n. 32. (Una delusione)' (1948) Archivio Penale 
Pugiotto A, 'Quando (e perché) la memoria nazionale si fa legge' in A. Pugiotto (ed), Per una consapevole cultura costituzionale. Lezioni magistrali (Jovene 2013)

Resta G, Zeno-Zencovich V, 'Judicial "Truth" and Historical "Truth": The Case of the Ardeatine Caves Massacre' (2013) 314 Law and History Review

Resta G, Zeno-Zencovich V (eds), Riparare, risarcire, ricordare. Un dialogo tra storici e giuristi (Editoriale scientifica 2012)

Rovatti T, Leoni vegetariani. La violenza fascista durante la RSI (Clueb 2011)

Santosuosso A, Colao F, Politici e amnistia. Tecniche di rinuncia alla pena per i reati politici dall'unità ad oggi (Bertani 1986)

Sartre JP, 'Qu'est-ce qu'un collaborateur?' (1945) La République Française

Seminara S, 'Die Aufarbeitung der faschistischen Vergangenheit in Italien.

Strafrechtliche Probleme' (2014) 15 Jahrbuch der Juristischen Zeitgeschichte

Tomasi di Lampedusa G, The Leopard (Collins 1960)

Traverso E, Il passato: istruzioni per l'uso. Storia, memoria, politica (Ombre Corte 2006)

Von Lingen K, Nuremberg, Rome, Tokyo: The Impact of Allied War Crimes Trials on Post-War Memory and Identity in Germany, Italy and Japan after 1945 (ESRI 2009)

Vassalli G, Sabatini G, Il collaborazionismo e l'amnistia politica nella giurisprudenza della Corte di Cassazione (La Giustizia penale 1947)

Woller H, Die Abrechnung mit dem Faschismus in Italien, 1943-1948 (Oldenbourg 1996) 